\title{
Economic threshold level of pear psyllid, Cacopsylla pyricola (hemiptera: psyllidae) On pear trees in Ismailia governorate
}

\author{
Youssef, A.S.; shaaban abd-rabou and S. F. M. Moussa \\ Plant protection institute, arc, dokki, giza, egypt.
}

Corresponding author: saberfahim@hotmail.com

\begin{abstract}
The economic threshold level is a key factor to be studied for control of pear psyllid, Cacopsylla pyricola (Foerster) which has been recorded as a key pest on pear trees in North Sinai and Ismailiya Governorates, Egypt (Ahmed, 2007). This pest caused considerable losses in pear fruit yield in most of pear orchards. Ecological studies showed that the seasonal abundance of this species begin to be active from early March and continued to mid June under climatic conditions of Ismailiya Governorate. The present study aims to evaluate the economic threshold level of infestation on pear trees. Results of statistical analysis showed, when population density of $C$. pyricola was (13.7 nymphs / twig) it could be regarded as an economic threshold of infestation with C. pyricola on pear trees, at this level it is sufficient time for initiation of control measures.
\end{abstract}

Keywords: Economic threshold, Cacopsylla pyricola, pear trees

\section{Introduction}

Pear psyllid, Cacopsylla pyricola (Foerster) (Homoptera: Psyllidae) was recorded as a new pest on pear trees in Egypt (Ahmed, 2007). The infestation of the pest causes many types of damage; leaves yellowish, local lesions due to toxic saliva, defoliation, loss in plant vigor and shrinking of fruits, then falling in premature stage. The nymphs and adults excrete large amounts of honeydew which encourage the growth of sooty mould and consequently the infested leaves acquire the dirty black appearance that effects photosynthesis. The collapse in growth and plant vigor cause a reduction in yield and (sometimes) death of the tree. Infested pear trees may recover if pear psyllid densities are kept low (Beers et al., 1993). The economic may be defined as the population density at which control measures are necessary to be applied to prevent eventual economic damage. Thus, before a monitoring plan can be implemented to provide control decisions, information about the threshold is required. Ecological and population studies showed that C. pyricola had a main period of seasonal abundance extending from early March to mid June. The seasonal abundance reached its peak of seasonal activity during April. During this period pear trees were at the time of sprouting of vegetative and appearance of floral buds. Therefore, the activity of this species was coinciding with the phenology of pear trees.

The present study aimed to evaluate of the economic threshold rate of infestation with pear psyllid, C. pyricola on pear trees in order to take the proper decision for control measures.

\section{Material and Methods}

To estimate the economic threshold level of infestation with $C$. pyricola to pear trees, pear orchard about 5 feddans was chosen in Ismailiya Governorate for this purpose. The pear trees, Pyrus communis cv. Le-Conte were about 10-11 years old. These trees received the same agricultural practices during the experimental period. From these trees, twenty trees of the same age, shape, size, vegetative growth and infestation with $C$. pyricola were selected for experimental purposes. The selected trees did not receive any insecticidal application during the experimental period. In order to determine the population density of, $C$. pyricola on the selected trees were counted at half monthly samples each consisting of 20 twigs about $(20 \mathrm{~cm}$ long) picked at random from each tree from January to December, 2013. These samples were kept in special plastic bags and transferred to the laboratory for counting the pest individuals by the aid of binocular stereo microscope. Counts involved estimation of the average number of alive nymphs and adult females per 20 twigs. To obtain different levels of infestation with this pest, the selected trees were divided into four groups (each of 5 trees). The first group was left without any insecticidal treatment, while the other three groups were sprayed on mid February, 2014 with Mineral oil (Supermox 95\% EC) at rates of $0.50,0.75$ and $1.0 \%$ for the three groups, respectively. To estimate the population density of this species, the twenty selected trees were enumerated and mean number of alive nymphs / twig were recorded weekly from mid March to end of August, 2014, and the average was calculated for each tree. During the harvest season on August, 2014 
total pear fruit yield of each tree was weighed and fruit yield in $\mathrm{kg}$. /tree was recorded. To estimate the economic threshold level of infestation due to infestation by $C$. pyricola, it was found that it is more convenient to use average number of nymphs / twig for each tree throughout the season as an independent factor (x). While, pear fruit weight in $\mathrm{kg}$. /tree was used as dependent factor (ỳ). When correlation coefficient value (r) was significant, regression coefficient (b) value was calculated using this formula:

$\grave{y}=a \pm b x$

Where: ỳ: Expected value

a: Constant

b: Regression coefficient

$\mathrm{x}$ : Mean number of nymphs / tree

This value was calculated at this stage to determine the slope of straight regression line. But since the yield population relationship was found to be more or less curved than linear, thus a curved regression line had to be fitted. The obtained values of (y) for each tree were arranged in descending order, while average numbers of nymphs / twig for each tree were arranged in ascending order. To achieve the point which the weight started to show a significant drop in the yield, the method of Chisquare analysis termed " $\mathrm{r} \times 2$ contingency tables with no exception" was applied to the (y) data. The following model elucidates this procedure:

$$
\chi^{2}=\Sigma \frac{(\mathrm{ni}-\mathrm{ei})^{2}}{\mathrm{ei}}
$$

Where:

$$
\begin{aligned}
& \chi^{2} \text { : Chi-square. } \\
& \text { ni : Observed yield. } \\
& \text { ei : Expected yield. }
\end{aligned}
$$

\section{Results and Discussion}

Data of the half monthly counts of $C$. pyricola on pear trees during, 2013 were illustrated in Fig. (1). It is showed that the pear psyllid had 2 annual generations per year. The first peak was in April and the second (lower peak) was in September, 2013. The pear fruit yield of pear variety (Le-Conte) was harvested during August. This means that the first generation (March to mid June and peaked in April) was the effective on pear yield. So, the obtained data of insect counts during the first peak of abundance statistically analyzed and correlated with the yield of pear fruits.

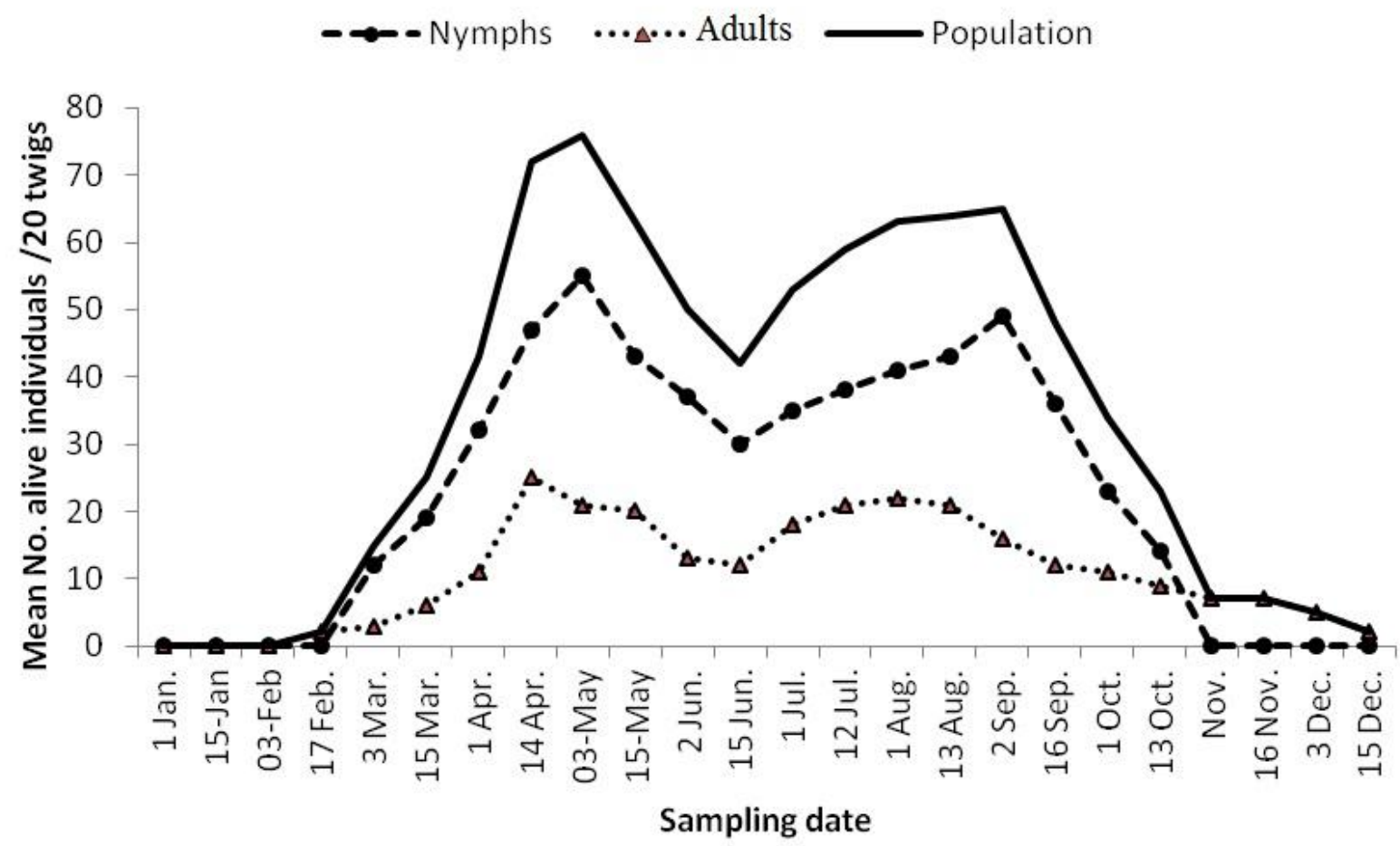

Fig. 1. Half-monthly fluctuations of $C$. pyricola on pear trees under natural climatic conditions in Ismailiya Governorate during, 2013. 
Effect of mean number of nymphs on pear fruit yield

Results obtained and statistically analyzed are given in Table (1) and graphically illustrated in Fig. (2). Data showed that the relationship between mean number of nymphs/ twig and pear fruit yield was negative and very highly significant. The correlation coefficient value was $\left(-0.966^{* *}\right)$. Also, the regression coefficient value was $(-0.182 * *)$. This means that as the population density of pear psyllid increased, pear fruit yield decreased.

From the aforementioned results, it could be stated that the population density of C. pyricola during main period of activity was found to be greatly affected the fruits yield. The injury caused by this pest was found to cause great damages to pear fruit yield of infested trees.

Table 1. Relationship between different levels of mean numbers of C. pyricola nymphs the activity period and pear fruit yield of 20 pear trees in Ismailiya Governorate during, 2014.

\begin{tabular}{ccc}
\hline Tree No. & $\begin{array}{c}\text { Mean } \\
\text { number of } \\
\text { nymphs / twig }\end{array}$ & Yield in kg. / tree \\
\hline 1 & 18.7 & 22.0 \\
2 & 25.5 & 15.0 \\
3 & 12.2 & 30.0 \\
4 & 29.0 & 14.0 \\
5 & 13.7 & 30.5 \\
6 & 14.0 & 29.5 \\
7 & 17.6 & 25.0 \\
8 & 52.2 & 10.0 \\
9 & 21.2 & 20.0 \\
10 & 36.8 & 12.0 \\
11 & 0.0 & 37.5 \\
12 & 13.9 & 30.0 \\
13 & 8.0 & 32.0 \\
14 & 31.1 & 14.0 \\
15 & 32.0 & 13.5 \\
16 & 27.9 & 14.5 \\
17 & 41.0 & 11.0 \\
18 & 45.3 & 11.0 \\
19 & 49.4 & 11.0 \\
\hline 20 & 22.4 & 20.0 \\
\hline & Simple correlation $(\mathrm{r})$ & $-0.966^{* *}$ \\
\hline
\end{tabular}

\section{Estimation of Economic Threshold Level of Infestation}

Results of statistical analysis showed that the population density of $C$. pyricola was highly significant correlated with fruit yield. Loss assessments were dependent on pear fruit yield losses. Estimation of "Economic Levels of Infestation" were based on the correlation between different levels of population density of $C$. pyricola and pear fruit yield per tree in order to take correct decision for control measures.

In is convenient to illustrate definition of some terms about "Economic threshold Level of Infestation" according to (Pedigo et al. 1986) and (Pedigo and Higley 1992).

In order to achieve this, the method of chisquare termed " $\mathrm{r}$ x 2 contingency tables" was applied to determine (ỳ) data. Also, percentages of yield losses were calculated at each level of infestation.
Results of statistical analysis are given in Table (2) and graphically illustrated in Figs. (2\&3).

The population density of $C$. pyricola during the main period of seasonal activity ranged between 0.0 to 12.2 nymphs / twig, the chi-square values for the yield (0.1140) was insignificant, denoting that the correspondent reduction in the yield which ranged from 37.5 to $30.0 \mathrm{~kg}$. / tree could be due to chance only. This level of infestation could be regarded as G.E.P. Afterwards, when population density reached 13.7 nymphs / twig; the corresponding yield was 40 $\mathrm{kg}$. / tree and chi-square value (0.51097) was indicating that significant drop occurred denoting the occurrence of marked mathematically reduction in the yield $(9.93 \%$ loss $)$ at that infestation level. Therefore, the infestation rate of 13.7 nymphs / twig could be regarded as the economic threshold level of infestation with $C$. pyricola on pear trees under weather conditions of Ismailiya Governorate. 
Table 2. Chi square analysis of pear yield with different levels of mean numbers of nymphs of $C$. pyricola on pear trees in Ismailiya Governorate during, year, 2014.

\begin{tabular}{cccc}
\hline $\begin{array}{c}\text { Mean No. of nymphs / } \\
\text { twig }\end{array}$ & $\begin{array}{c}\text { Observed yield } \\
(\mathrm{kg} .) / \text { tree }\end{array}$ & Expected yield (kg.)/tree & $\chi^{2}$ \\
\hline 0.0 & 37.5 & 41.5 & 0.383709 \\
8.0 & 32.0 & 32.4 & 0.005187 \\
12.2 & 30.0 & 28.2 & 0.114021 \\
13.7 & 30.5 & 26.8 & 0.510971 \\
13.9 & 30.0 & 26.6 & 0.430353 \\
14.0 & 29.5 & 26.5 & 0.333908 \\
17.6 & 25.0 & 23.4 & 0.113319 \\
18.7 & 22.0 & 22.5 & 0.009686 \\
21.2 & 20.0 & 20.5 & 0.012498 \\
22.4 & 20.0 & 19.6 & 0.007590 \\
25.5 & 15.0 & 17.5 & 0.345616 \\
27.9 & 14.5 & 15.9 & 0.128507 \\
29.0 & 14.0 & 15.3 & 0.106264 \\
31.1 & 14.0 & 14.1 & 0.000627 \\
32.0 & 13.5 & 13.6 & 0.001022 \\
36.8 & 12.0 & 11.4 & 0.033752 \\
41.0 & 11.0 & 9.8 & 0.137248 \\
45.3 & 11.0 & 8.7 & 0.631618 \\
49.4 & 11.0 & 7.9 & 1.199860 \\
52.2 & 10.0 & 7.6 & 0.741454 \\
\hline
\end{tabular}

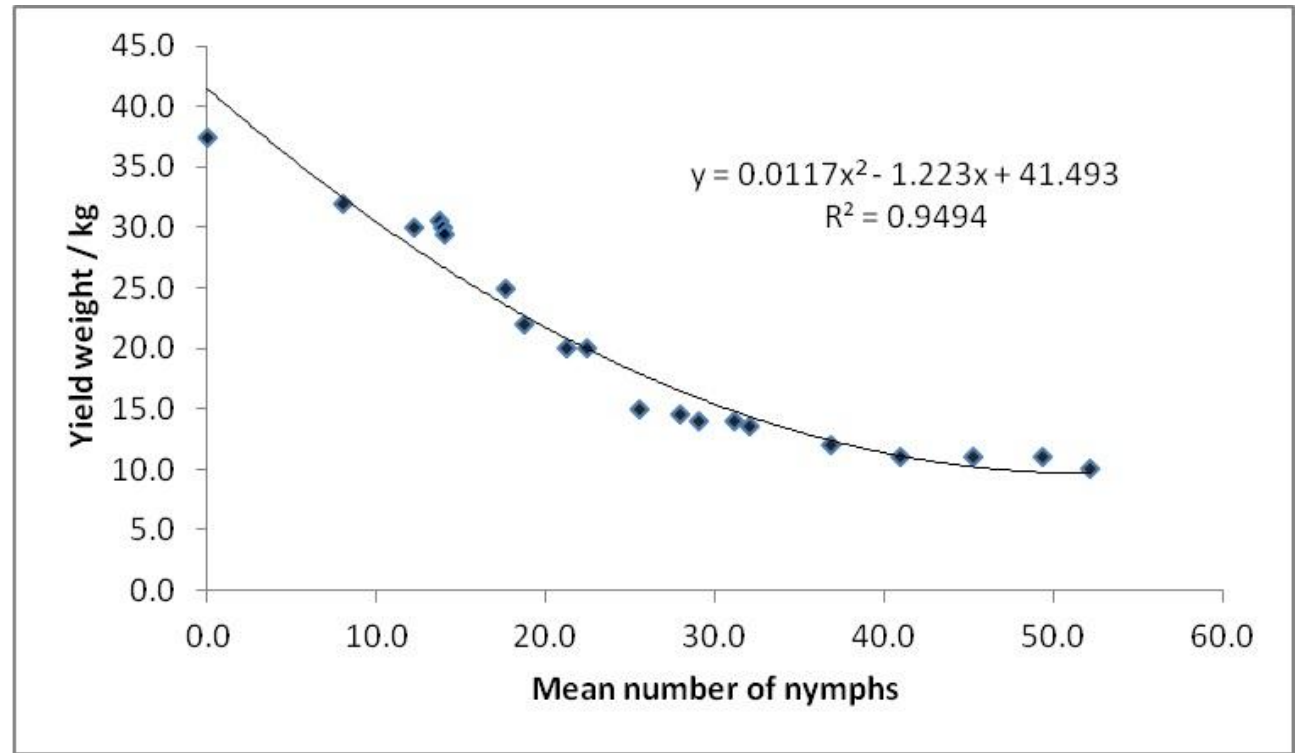

Fig. (2): The corrected average weights of pear fruit yield / unit (ỳ) in relation to $C$. pyricola infestation rates (x) during, 2014, on pear trees in Ismailiya Governorate. 


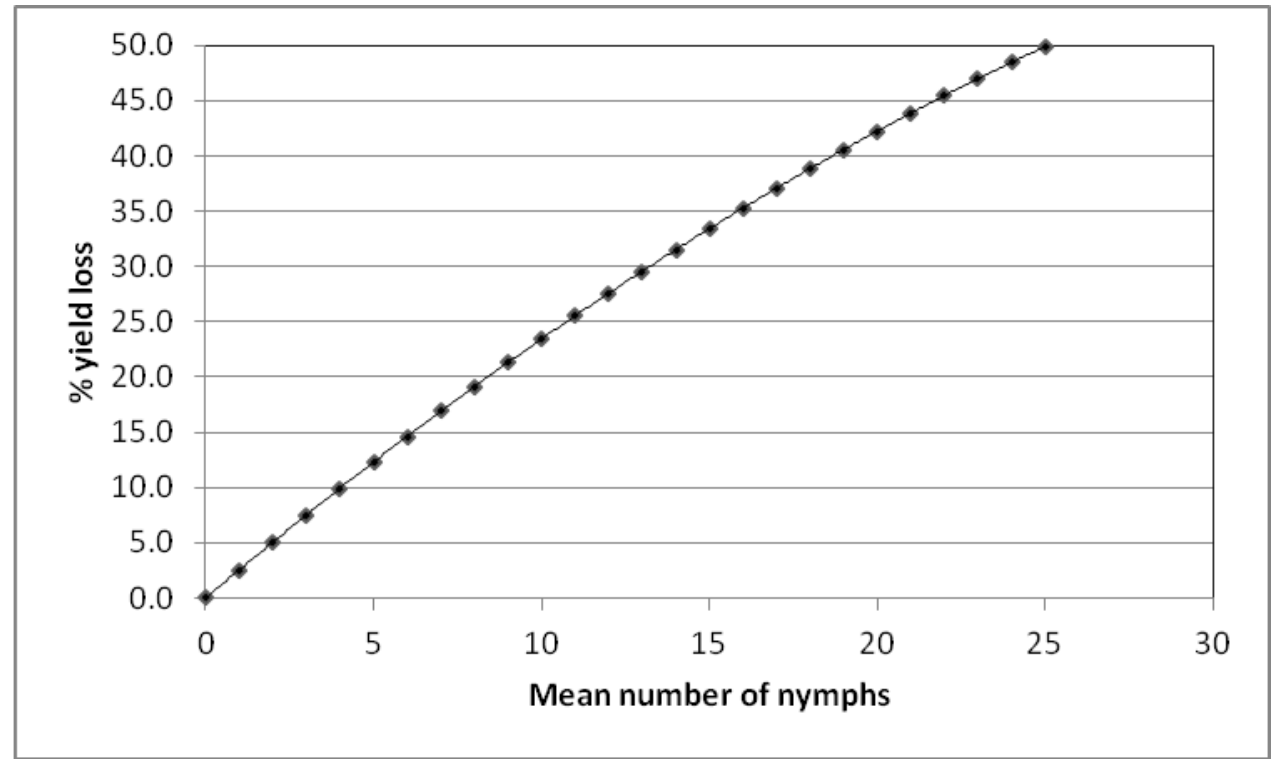

Fig. (3): The relationship between mean numbers of $C$. pyricola nymphs (x) and the correspondent percentages of yield losses in pear fruit yield / unit (ỳ) in Ismailiya Governorate.

The present results agree to those obtained by (Westigard et al., 1979), (Burts, 1988), (Julien, 1984), (Savinelli and Tetrault, 1984) and (Rapisarda and Siscaro, 1990) reported that, the threshold density of pear psyllid, $C$. pyricola may be comparatively high or low, depending upon the type of damage to be prevented. For example, psylla shock is generally assumed to require quite high densities of nymphs. Also, age of the fruit, when it is contacted by honeydew may affect extent of the damage, indicating that thresholds vary seasonally. It seems to be generally accepted that early-season injury is more costly than later-season damage, and that thresholds are thus lower early in the season. Injury due to psylla shock is generally thought to require high densities of nymphs, perhaps occurring over a period of several years.

\section{References}

Ahmed, S. A. (2007): Description of the pear psyllid, Cacopsylla pyricola (Foerster) (Hemiptera: Psyllidae), a new record in pear orchards in North Sinai and Ismailia Governorates, Egypt. Egyptian Journal of Biological Pest Control Vol. 17 No. 1/2:159 -160 pp.

Beers, E.H., Brunner, J.F., Willet, M.J. and Warner, G.M. (1993): Orchard Pest Management: A
Resource Book for the Pacific Northwest. Yakima, WA: Good Fruit Grower.

Burts, E.C. (1988): Damage threshold for pear psylla nymphs (Hemiptera: Psyllidae). J. Econ. Entomol. 81: 599-601.

Julien, J. (1984): The economic importance of pear psyllids for the production of pears in France. IOBC/WPRS Bull. 7:7-12.

Rapisarda, C. and Siscaro, G. (1990): Notes on the pear psyllids of Sicily. Tec. Agric. (Catania), 42: 31-44.

Pedigo, L.P., S.H. Hutchins and L.G. Higley (1986): Economic injury levels in theory and practice. Ann. Rev. Entom., 31: 341-368.

Pedigo, K. P. and L. G. Higley. 1992: The economic injury level concept and environmental quality: a new perspective. American Entomologist, 38:12-21.

Savinelli, C.E. and Tetrault, R.C. (1984): Analysis of pear psylla (Homoptera: Psyllidae) populations and associated damage in a Pennsylvania pear orchard. Environ. Entomol. 13: 278-81.

Westigard, P.H., Lombard, P.B. and Berry, D.W. (1979): Integrated Pest Management of Insects and Mites Attacking Pears in Southern Oregon. Oregon State University, Agricultural Experiment Station Bulletin 634, Corvallis, OR: $41 \mathrm{pp}$. 


\section{Cacopsylla pyricola (Foerster) الحد الإقتصادى الحرج لحشرة سيلد الكمثرى على أشجار الكمثرى فى محافظة الإسماعيلية}

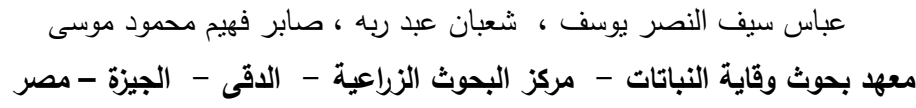

سجلت حشرة سيلا الكمثرى فى بعض مزارع الكثرى بمحافظتى شمال سيناء والإسماعيلية عام 2007 ، وقد سبيت خسائر

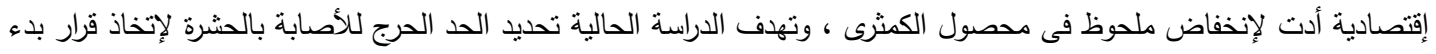

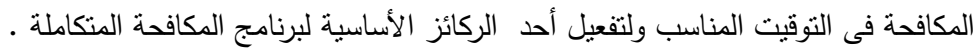

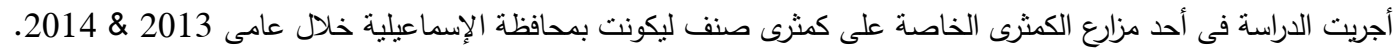

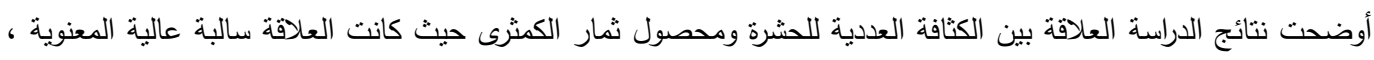
(قيمة الارتباط البسيط = -0.966") أى أنه كلما زادت الكثافة العددية للحشرة أنخفض محصول ثمار الكمثرى ، بناءاً على الكئ العلاقة بين الكثافات العددية المختلفة لحشرة سيليد الكمثرى ممثلة فى أعداد الحوريات/غصن بطول20سم (ألثاء فتزرة النشاط الرئيسية

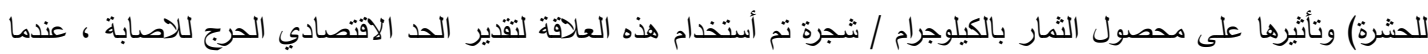

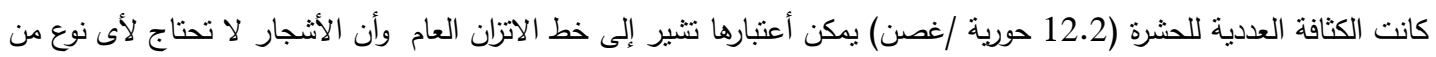

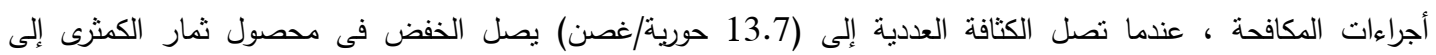
(9.93\%) ، يمكن أعتبارها تمثل الحد الاقتصادى الحرج حيث تبدأ عند هذا الحد إنخاذ أجراءات المكافحة لمنع زيادة الكثافة العددية الكالية

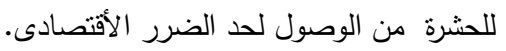

